Article

\title{
The Discussions around Precision Genetic Engineering: Role of and Impact on Disabled People
}

\author{
Gregor Wolbring * and Lucy Diep \\ Department of Community Health Sciences, Stream of Community Rehabilitation and Disability Studies, \\ University of Calgary, 3330 Hospital Drive NW, Calgary, AB T2N 4N1, Canada; ldiep@ucalgary.ca \\ * Correspondence: gwolbrin@ucalgary.ca; Tel.: +1-403-210-7083
}

Academic Editor: Maya Sabatello

Received: 19 February 2016; Accepted: 5 September 2016; Published: 9 September 2016

\begin{abstract}
Genetic researchers are advancing in their abilities to extract precise genetic information from biological and human entities bringing genetic research steps closer to accurately modifying genes of biological entities, including that of humans. In this analytical essay, we focus on the discussions about precision genetic intervention that have taken place since March 2015 as they pertain to disabled people. We focus on two areas; one being the role of disabled people in the recent gene editing discussions and the second being the utility of existing legal instruments. Within our first focus we address the following questions: (a) What is the visibility of disabled people in the gene-editing discussions that have taken place since March 2015? (b) What has been the impact of those discussions on disabled people? (c) Were social problems which disabled people face taken into account in those discussions; (d) How does the reality of engagement with disabled people in these discussions fit with science, technology and innovation governance discourses that ask for more stakeholder, bottom up and anticipatory involvement? Within our second focus we address the following questions: (a) What is the utility of the United Nations Convention on the Right of Persons with Disabilities (UNCRPD); and (b) What is the utility of existing legal instruments covering genetic interventions: for preventing negative social consequences of genetic engineering developments for disabled people. We argue that (a) the genetic engineering debates since March 2015 have portrayed disabled people dominantly through a medical lens; (b) that the governance of science, technology and innovation of genetic engineering including anticipatory governance and responsible innovation discourses has not yet engaged with the social impact of gene editing on disabled people; (c) that few scholars that focus on the social situation of disabled people are visible in the governance discussions of gene editing; and (d) that the utility of the UNCRPD and the investigated genetic-related legal instruments and international agreements to protect disabled people from negative consequences coming out of the gene editing discussions is unclear at the least.
\end{abstract}

Keywords: law; disabled people; people with disabilities; genetic engineering; gene-editing; genetic enhancement; somatic; germline; United Nations Convention on the Rights of Persons with Disabilities; governance

\section{Introduction}

Genetic related products and interventions have been advanced and discussed for some time. Precision genetic engineering includes somatic and germline genetic manipulations and the synthesis of genomes from the base pair level up. In this analytical essay, we interrogate the recent discussion around gene editing and its impact in relation to disabled people and the utility of the United Nations Convention on the Right of Persons with Disabilities (UNCRPD) and legal instruments covering genetic interventions for protecting disabled people from negative social impacts. We employ in our analytical essay a disability rights approach lens which focuses on the social situation of disabled people. This 
interrogation has been brought forward for the following reasons: (a) the area of gene editing is still in development and as such fits with the premise of anticipatory governance where a discussion around the topic should take place before the product is in place; (b) discussions around gene editing impact how we look at other areas of genetic interventions such as preimplantation genetic interventions [1,2]; (c) gene editing applications will not only be used as an approach for fixing a genetic "defect" based on species typical ability expectations but it will expand into the area of generating "new" or "improved" abilities; and (d) genetic enhancement agendas are influencing discourses around what is considered to be a disease or an impairment. We focused on disabled people using a disability rights approach because how gene editing is discussed (a) impacts the perception of disabled people, whereby how we portray disabled people is still being contested [3-11]; (b) impacts the narrative around what we see as the cause of disablement; (c) impacts the narratives of other genetic interventions such as prenatal genetic testing and pre-implantation genetic diagnostics. We also have the assumption that a disability rights approach would benefit the discussions around gene-editing because the judgment of abilities one ought to have and the consequences of one not fulfilling ability expectations is a main focus of a disability rights approach and part of the academic fields of disability studies and ability studies. We posit that the societal dynamic of ability expectations and how we govern ability expectations will be a major factor in deciding the scope of use of gene editing including whether we use it for human enhancement.

\subsection{Precision Genetic Interventions}

Somatic and germline modifications and genomic synthesis have been discussed for some time; however, the debate around human gene editing intensified in March $2015[2,12,13]$ when a study was published describing the germline genetic modification of human embryos [14]. Beyond human germline editing, there are several other applications envisioned for gene editing [15-17]: gene editing also allows synthetic biologists to design and edit whole genomes of biological entities giving them new properties [18]; genome-scale engineering is pursued as a strategy for the design and optimization of cellular functions $[19,20]$. An International Summit on Human Gene Editing took place 1-3 December 2015 as a result of these discussions [21].

Some of the issues discussed relating to gene editing included genetic selection, somatic and germline genetic interventions, interventions aimed at preventing disease, interventions aimed at gene enhancements "to provide improved traits and abilities" [22], in vitro and in vivo gamete modification, in vitro and in vivo embryo modification, and in vivo fetal modification [23]. Each of these issues and approaches will pose different challenges for domestic and international regulation and guidelines.

\subsection{Precision Genetic Interventions: The Case of Germline Interventions}

One particular area of focus in the debates that arose since March 2015 was the procedure of germline modification. Various groups questioned the use of germline interventions; the Society for Developmental Biology asked for a "voluntary moratorium by members of the scientific community on all manipulations of pre-implantation human embryos by gene editing", and The American Society for Gene and Cell Therapy asked for a "strong ban on human germ-line gene editing or other germ-line genetic modification" until a time when a "societal consensus [has been] reached" [24]. Human germline gene modification for reproductive purposes is prohibited in many countries over concerns of medical beneficence, safety, challenges to human dignity, and risk of abuse for eugenics or enhancement for non-medical reasons [25]. However, certain reasons for prohibitions such as safety concerns are seen as temporary ones [25]. Some say that one must focus one's therapeutic efforts on somatic cells and that one should apply the current regulatory framework of somatic cell gene modification to medical intervention [26].

On the other hand, many defend germline modification arguing that it relieves "parents of the distress that stems from their genetic condition" [27]; that "patients would also favorably view the treatment because a child born of germline genome editing and the subsequent generations would 
not be expected to develop the genetic disease" [27]; that "it could minimize the use of burdensome procedures such as oocyte stimulation and selective abortion following prenatal diagnosis" [28]; and that it precludes or minimizes the need for oocyte donation [28]. According to Adashi: "subject to a few exceptions, dominant elements of the biomedical universe are content to further explore the prospect of editing the genome of the human germline in the research realm" [24]. Ronald Green examined five questions: (1) Will genetic modifications risk the health of the resulting children? (2) Will modifications reduce the willingness of parents to love and accept their children? (3) Will genetically modified individuals suffer a reduced sense of freedom or self-esteem? (4) Will genetic interventions heighten social injustice? (5) Does human genetic engineering amount to a sinful "playing God"? [22]. In asking these questions, Green gave the following recommendations:

(1) Genetic interventions should always be aimed at what is reasonably in the child's best interests;

(2) Genetic interventions should be almost as safe as natural reproduction;

(3) We should avoid and discourage interventions that confer only positional advantage. This guideline addresses interventions aimed only at competitive success. Such interventions-shown in their crassest form in sports doping-lead competitors to subject themselves to increased health risks, whether from drugs or risky gene modifications, for little benefit because all competitors are soon compelled to do adopt them;

(4) Genetic interventions should not reinforce or increase unjust inequality and discrimination, economic inequality, or racism. Neither race nor sex nor sexual orientation is a condition intrinsically needing genetic intervention. Any suffering resulting from these conditions derives from unjustified discrimination. If parents, in the effort to ease their child's burdens, use genetic engineering to change the child's skin color, sex, or sexual orientation, they risk fostering discriminatory attitudes and practices. In such cases, it is better to change social attitudes than to alter a child's genes [22].

\subsection{Precision Genetic Interventions: The Issue of Genetic Enhancement}

Genetic enhancement is one specific application discussed around genetic interventions. Many involved in discussions of genetic enhancement have drawn the line between therapeutic versus enhancement interventions invoking, for example, consumer eugenics and a multitier social system based on certain enhancements [29]. Others indicate that this line is rather ambiguous [30,31] and that genome editing-mediated enhancement will likely be offered in certain countries [25]. One author points out that Section 5 of the German Embryo protection law (ESchG) prohibits germline interventions but not for the reason of preventing positive eugenics (i.e., individual "enhancement" demands) but rather because of related technical problems [31]. The International Summit on Human Gene Editing released a statement with four conclusions whereby the conclusion on the clinical applications of germline editing stated [21]: "Gene editing might also be used, in principle, to make genetic alterations in gametes or embryos, which will be carried by all of the cells of a resulting child and will be passed on to subsequent generations as part of the human gene pool. Examples that have been proposed range from avoidance of severe inherited diseases to 'enhancement' of human capabilities. Such modifications of human genomes might include the introduction of naturally occurring variants or totally novel genetic changes thought to be beneficial" [21]. Although the statement did not propose a ban on germline enhancement, the members of the organizing committee issued a qualifier stating: "It would be irresponsible to proceed with any clinical use of germline editing unless and until (i) the relevant safety and efficacy issues have been resolved, based on appropriate understanding and balancing of risks, potential benefits, and alternatives; and (ii) there is broad societal consensus about the appropriateness of the proposed application" [21].

This analytical essay is organized the following way. In Section 2, we discuss the topic of public engagement whereby we answer the questions: How are disabled people portrayed in the debates of precision genetic intervention such as gene and genomic engineering (Section 2.2.1)? Are disabled 
people seen as being impacted by the problems identified in these debates? How are disabled people impacted by the problems identified (Section 2.2.2)? How does the reality of engagement with disabled people in these discussions fit with science, technology and innovation governance discourses that ask for more stakeholder, bottom up and anticipatory involvement (Section 2.2.3)? In Section 3, we discuss the utility of the UNCRPD and legal instruments covering genetic interventions for preventing negative consequences of genetic engineering developments on the social situation of disabled people including the health and wellbeing of disabled people.

\section{The Case of Public Engagement}

\subsection{Background}

Various science, technology and innovation governance frameworks focus on public engagement. The framework of anticipatory governance (AG), for example, entails four elements: foresight (constructing plausible socio-technical implications), integration (bringing together diverse fields such as social sciences and natural sciences), engagement (bringing together public citizens, developers, engineers, policy-makers, and other actors to construct conversations around awareness, reaction, and knowledge development and sharing), and ensemblization which brings together the three elements [32,33]. Anticipatory governance has been defined as a way to "[amplify] the still, small voices less often heard in the innovation process" [34]. Responsible innovation (RI) is another framework that places a large emphasis on the interplay between science and society, and the consideration of societal values in the research and design process [35]. The European Commission (EC) identified eight dimensions of RI: "engagement", "gender equality", "science education”, “ethics", "open access", "governance", "sustainability" and "social justice/inclusion" [36].

The Convention for the Protection of Human Rights and Dignity of the Human Being with regard to the Application of Biology and Medicine: Convention on Human Rights and Biomedicine [37], states in Article 28 on Public debate: "Parties to this Convention shall see to it that the fundamental questions raised by the developments of biology and medicine are the subject of appropriate public discussion in the light, in particular, of relevant medical, social, economic, ethical and legal implications, and that their possible application is made the subject of appropriate consultation" [37]. Public engagement is called for in plant biotechnology [38], biotechnology [39], nanobiotechnology [40,41], human enhancement [42], genomic studies [43], large cohort genetic research [44], precision medicine [45], biobanking [46] and genetic testing [47], to mention a few. Public engagement is also called for in various areas of precision genetic and genomic engineering such as prenatal gene therapy [48], synthetic biology [49-52], somatic and germline genetic interventions [13,23,53-55]. Sugarman sees the need for "representation from a broad range of stakeholders with legitimate interests and expertise to meaningfully engage in a fair process" [28]. According to the Hinxton group, an international consortium on stem cells, ethics and law, it is "critical to scientific and societal decisions about the use of genome editing for basic research and clinical reproductive purposes" to have "appropriate governance and oversight, and meaningful and substantial public engagement" [23]. The International Summit on Human Gene Editing Summit statement [21] calls on the hosts of the summit-the U.S. National Academy of Sciences and U.S. National Academy of Medicine, the Royal Society, and the Chinese Academy of Sciences-to create "an ongoing international forum to discuss potential clinical uses of gene editing; help inform decisions by national policymakers and others; formulate recommendations and guidelines; and promote coordination among nations." The Summit statement outlines further that the forum should "engage a wide range of perspectives and expertise-including from biomedical scientists, social scientists, ethicists, health care providers, patients and their families, people with disabilities, policymakers, regulators, research funders, faith leaders, public interest advocates, industry representatives, and members of the general public" [21]. The summary brief of the summit gave voice to Benjamin and Baylis who "both noted the importance of including diverse perspectives so that assessments of risks and benefits are not limited to medical risks alone" and to 
Charis Thompson who believes that the "public interest advocates in the fields of disability rights, racial justice, women's health, reproductive rights and justice, the LGBT community, environmental protection, and labor, as well as members of the general public have to be heard" [56].

At the same time, public engagement has been linked to the portrayal of the public as a passive recipient [1]: "The public must also be made aware of what is legitimate and what is not, which will in turn require robust communication from authorities as well as from scientists and clinicians" [12].

\subsection{The Role of Disabled People as Members of the Public}

Disabled people are members of the public. In this analytical essay, we raise three questions on the role of disabled people as part of the genetic intervention discourse. In Section 2.2.1, we discuss how disabled people are portrayed in the genetic intervention discourses. In Section 2.2.2, we discuss whether issues facing disabled people are recognized within the genetic intervention discourse, and if yes, which issues? In Section 2.2.3, we discuss whether disabled people are visible within the genetic intervention discourses including the governance of genetic intervention discourses.

\subsubsection{The Portrayal of Disabled People within the Genetic Intervention Discourses}

Possible Portrayals of Disability So Far

The question of "what is a disability" has been a long standing debate (for example [3-11]). Independent of where one stands on the topic, there are two aspects to the issue of disability: (i) how the body is defined; and (ii) what one perceives as disabling. The following narrative combinations of body, perception of disablement and interventions are possible:

The first narrative is purely medical, whereby the body is seen as impaired as a result of not having certain abilities deemed as essential (medical characterization of the body) and where the disablement experienced by the person is seen to originate from within the body (medical origination of disablement). As such the focus is on "fixing" the person, at the genetic level, toward a species typical norm (medical understanding of cure) [57-61].

The second is a medical narrative of the body/social narrative of the disablement and cure. In this case, the person is still described as impaired as they do not fulfill species-typical ability expectations (medical understanding of the body), however, the disablement the person experiences is located outside of the body within the person's surrounding social and physical environment (social origination of the disablement). The focus is on fixing the social parameters seen to disable the person (social understanding of cure).

The third narrative is purely non-medical whereby the person does not accept that the ability differences exhibited by the body are an impairment but are seen as differences of abilities (diversity understanding of the body); see Deaf Culture [62-65], or the discourse around neurodiversity [66-69]. The disablement experienced is a result of the person's surrounding social and physical environment (social origination of disablement). The focus is on fixing the social and physical environment (social understanding of cure) [57-61].

In short, a person can experience the following combination of disablement given the characterizations of the body, the disablement that a person experiences, and the interventions: (a) medical/medical/medical; (b) medical/social/social; and (c) social/social/social.

People who identify with the medical model of the body can identify and experience both medical and social disablements and might seek both medical and social cures. However, the question arises whether (a) they have the power to decide what disablement they experience; and (b) what cures they seek? The question is who gets to decide which characterization of the body, which characterization of the origin of the disablement and which intervention focus is the right one? A lively debate has existed for some time around the origin of disablement and how a body exhibiting ability differences should be defined. It has been stated that "many disabled people perceive themselves in a cultural identity war with the so called non-disabled people where their self-identity understanding of being 
ability diverse and ability variant, as being a culture and not being ability deviant and ability deficient is rejected by many" [70]. Debate and discussions are underway for many ability differences which are labelled as disorders or diseases as to whether these ability differences are an impairment, disease or neither (for example, see discussion around Deaf culture, neurodiversity and Down Syndrome); the writings of ethicist Harris and others [71-73] on the validity of perceiving body ability differences not as the cause of disablement or impairment but as variations. In one of the commissioned papers for the International Summit on Human Gene Editing, it is stated: "As the disability studies scholar Tom Shakespeare commented, "To fix a genetic variation that causes a rare disease may seem an obvious act of beneficence. But such intervention assumes that there is robust consensus about the boundaries between normal variation and disability". Indeed, there is not, even though that distinction has become ubiquitous in reporting on gene editing" [74]. Further, the summary brief of the International Summit on Human Gene Editing remarks: "Ruha Benjamin (Princeton University) pointed out that the line between diversity and disability is fuzzy, and that biomedical researchers can overlook and thereby reinforce stigma and social disparity by treating certain conditions as disabilities that need to be "fixed" through biomedical interventions" [56].

The distribution of efforts between medical and social interventions where the body is portrayed as dominantly medical continues to be debated. People discuss within and outside the genetic debate whether one can be in favor of termination (medical) and still support the social cures of accommodating the existing ability of different people [11,75-79]. The write up summary of the International Summit on Human Gene Editing stated that Sharon Terry of the Genetic Alliance "reminded the audience that members of patient communities are fighting hard to eliminate diseases while also working to change physical and social environments so that all people can live productive and fulfilling lives" [56], yet others believe that the focus on a medical fix, or deselection actions is decreasing the social situation of disabled people (for an overview of arguments see for example [80]).

Enhancement, the New Player in the Game of Disability Portrayal

A new narrative in gene-editing which is gaining traction is the enhancement narrative where any non-enhanced body is seen as defective (medical enhancement model of the body) and as the originator of disablement (medical enhancement understanding of disablement). The focus is on "fixing", including genetically, the non-enhanced person in order for them to have functions that are beyond the species typical norm (medical enhancement understanding of cure) [57-61].

The Portrayal of Disabled People within the Genetic Intervention Discourses

Of these different narrative options, the discourses around genetic editing predominantly exhibit a medical model of the body, the disablement and the cure sentiment.

The "medical" narrative of gene editing interventions is evident in the concluding statement of the International Summit on Human Gene Editing [21]. The medical narrative is also evident in documents by groups in opposition of germline gene editing:

Gene editing may hold some promise for somatic gene therapy (aimed at treating impaired tissues in a fully formed person). However, there is no medical justification for modifying human embryos or gametes in an effort to alter the genes of a future child. Parents who wish to have children unaffected by genetic diseases can almost always accomplish this through other methods, including conventional embryo screening and selection procedures. While screening future children also raises significant ethical implications, it is far safer than experimentally manipulating the DNA of germ cells to produce genetically modified babies, and has less potential for widespread societal disruption [81].

When groups who are in opposition of germline gene editing use the medical narrative as their supporting argument, it ignores that what is seen as medical is based on contested ground (see for example [62-65,68,70,82-92]) and it ignores the potential negative consequences that come 
with a medical label. It may be advantageous for parties that want to push germline gene editing to use the medical narrative; however, the use of the medical narrative by groups with a social justice angle to support their case against germline gene editing seems contradictory to their social justice focus and cause.

Ultimately, the medical narrative has often been detrimental to disabled people having a voice in the governance of science and technology. The strategy of using the medical narrative as a demarcation line has been used before by both sides (the side selling genetic testing and the side claiming that their characteristic should not be tested for because their characteristic is not a medical one $[93,94])$ to set the boundaries of genetic testing whereby disabled people were identified as being "diseased" [93]. In the discourse around the use of genetic tests, an "Animal Farm" philosophy is evident [94] where its non-medical use is viewed as problematic and its medical use is deemed acceptable. As such, it is important to understand the issues around the medicalization of bodies and ability differences because once bodies become medicalized, they get separated from the moral and ethical reasoning which is considered for the non-medicalized body.

Another important issue is whether social problems are identified that may impact disabled people in the wake of the genetic intervention discourses.

\subsubsection{The Problems Disabled People Face}

The literature around gene editing has raised several problems but none of the problems raised have been linked to disabled people.

The Hinxton statement covers safety issues linked to gene editing from a purely medical angle [23] but does not cover the social safety of disabled people. The statement poses that "policies governing science nationally and internationally ought to be flexible, so as to accommodate the rapidity of scientific advance as well as changes of social values [23]" but it does not address or clarify what falls under social values and in accordance to whose values?

An upstream engagement is envisioned to take place which incorporates social values into the research and development and governance of science and technology [95], but again, whose values count? The Hinxton group states: "Any constraint of scientific inquiry should be derived from reasonable concerns about demonstrable risks of harm to persons, societal institutions, or society as a whole" [23] but where does that leave disabled people especially with disability rights concerns? Are disability rights concerns seen as reasonable? So far, disabled people's rights views have not been regarded as a reasonable justification within the advancements of genetic testing or genetic discrimination debates [96] and as such it is doubtful that they will be considered reasonable now.

Furthermore, at least two members of the Hinxton group do not agree with the disability rights community on how to perceive and label body ability difference (Harris [71-73] and Savulescu [97-99]). The Hinxton group states further: "Policymakers should refrain from constraining scientific inquiry unless there is substantial justification for doing so that reaches beyond disagreements based solely on divergent moral convictions" [23]. Based on this statement, will a disability rights angle ever be considered as enough of a substantial justification? Given the history of the genetic discussions so far, we posit that the answer will be "No". So, where does this leave disabled people? One consequence that can already be observed in the discussion around germline gene editing is the fact that there are other genetic procedures, namely preimplantation genetic diagnosis (PGD) and somatic interventions, which are being sold as acceptable procedures even though discussions and concerns surrounding these procedures are far from resolved [2]. This impacts disabled people who question still the use of PGD or the narrative around somatic gene interventions.

Gene-editing methods are platform technologies. If gene-editing will be deemed to be safe it could be applied at the somatic and germline level and for all kinds of gene differences which will influence the discourses around what is a disability in the same way that genetic testing influenced this debate. It will also increase discussions around whether persons currently viewed as "normal" are impaired. Given that the procedure could just as well be used to change gene based abilities that are 
now seen as "normal" to push for enhancement applications, it seems reasonable that what is seen as "normal" might be up for debate. Indeed, if gene editing achieves a precision that gene modifications will only change what is envisioned to be changed it opens up the door that any gene, based on the abilities it generates, could be seen as in need of "improvement". That changes drastically the scope of what "normal" can be questioned.

At least two members of the Hinxton group promote human enhancement (Harris and Savulescu, for a comment see [100]) as do others in the discourse of gene editing and disabled people are impacted by the human enhancement debate in various ways. One way is that the medicalization of the species-typical puts the species-typical "unhealthy" in competition with the sub species-typical "unhealthy" (people labelled as impaired so far) with respect to areas such as resources, education and occupation [58,101-103]. However, the impact of enhancements on the social situation of disabled people has not been noted as an area of impact in gene editing discussions.

A third important issue is how visible are disabled people in the genetic intervention discourses, especially the governance of genetic intervention discourses.

\subsubsection{The Visibility of Disabled People within the Genetic Intervention Discourses}

Given that the medical narrative is used by both sides (those in support of gene editing and those in opposition of gene editing) as main arguments to support their case (see Section 2.2.1), it may be understandable why the disability rights voice is mostly absent from discussion of precision genetic interventions such as gene editing. Since the influx of discussions on gene editing from March 2015, there have only been two publications which highlight the problems of gene editing and its impact on disabled people from a disability rights perspective which focuses on how to improve the social situation of disabled people and how to prevent the worsening of the social situation of disabled people [1,104]. The commissioned papers for the International Summit on Human Gene Editing noted that a disability rights perspective was largely missing [74]. The lack of presence and support for disabled people's rights voice has also been acknowledged within the genetic testing debate $[91,92,96,105]$; however, the problem goes beyond genetic discourses. Disabled people are hardly represented in science and technology governance discourses in general. The 1999 UNESCO World Conference on Science, Declaration on Science Article 25 [106], articulated the missing voice of disabled people and others stating "that there are barriers which have precluded the full participation of other groups, of both sexes, including disabled people, indigenous peoples and ethnic minorities, hereafter referred to as disadvantaged groups". The Declaration on Science outlined suggestions for change in various articles covering areas such as the need for science education (Article 34) and equal access to science (Article 42) [106]. In the Science Agenda-Framework for Action document of the same conference [107], Articles 17, 41 59, 79, 81 and 91 mentioned the term "disadvantaged groups" (see Article 25 of the Declaration of Science [106]) and indicated the need for (a) "Initiatives to fully incorporate women scientists and other disadvantaged groups from the South and North into scientific networks"(Article 17); (b) "improving science education at all levels, with particular attention to the elimination of the effects of gender bias and bias against disadvantaged groups" (Article 41); (c) data disaggregated by gender and disadvantaged groups (Article 59); (d) full participation of disadvantaged groups in all aspects of research activities, including the development of policy (Article 79); and (e) "Governments and educational institutions should identify and eliminate, from the early learning stages on, educational practices that have a discriminatory effect, so as to increase the successful participation in science of individuals from all sectors of society, including disadvantaged groups" [107]. Article 91 focused exclusively on disadvantaged groups and the need to ensure their full participation in science and technology whereby the following was stated as action items: "removing barriers in the education system; removing barriers in the research system; raising awareness of the contribution of these groups to science and technology in order to overcome existing stereotypes; undertaking research, supported by the collection of data, documenting constraints; monitoring implementation of and documenting best practices and ensuring representation in policy-making bodies and forums" [107]. 
Still, most of these recommendations have not been acted upon. Finally, the invisibility of disabled people is not limited to the science and technology discourses but is an ongoing concern in many areas [108]. The phrase "nothing about us without us" is used by disabled people because they feel invisible in policy and many other discourses [109]. The question is: What to do?

We suggest that the following questions, at least, have to be addressed in the science, technology and innovation governance discourses, including the anticipatory governance (AG) and responsible innovation (RI) discourses, if an increase in participation of disabled people is to be achieved in general which includes the gene editing discourses. Who will provide for the societal environment that allows disabled people to take part which includes physical access, accessibility of the information material, and access to education that allows disabled people to identify problems? Will disabled people have the ability to provide and inform the network of groups involved in the governance of science, technology and innovation and who within the networks will decide who that network includes? Will disabled people have the ability to access the information needed for them to know that they should get involved and to be able to evaluate the situation? Will disabled people have the ability to know early enough that they have to be informed so that they can influence the anticipatory governance discourse of topics such as gene editing before the trajectory is already set [110]? Will disabled people have the ability to get involved; that is, will they not be hindered by the struggles of daily life given that the majority of disabled people are unemployed [111,112], that many disabled people still fight to obtain basic needs and live in poverty $[109,113]$ and given all the other problems disabled people face as evident in the UNCRPD [114] which might give little room for other endeavors? Who will be able to understand the issue?

At this time, the questions we posed generate negative answers for disabled people with a lot of work to be done. Participants of the discussion forum disability and the Post 2015 development goal agenda [115] "highlighted that the stereotypical understanding of disabled people within a medical framework precludes them from being part of certain discourses as the focus towards them is about preventing "disability" as in ill health not about decreasing their low social health" [108]. This suggests that one main action that should be taken is to thematize the impact of the medical narrative on the ability of disabled people that focuses on the social situation of disabled people to contribute to the science, technology and innovation governance discourses. Another action should be to add the impact on social health of disabled people as a topic which would allow disabled people to contribute to the governance of science, technology and innovation. Participants of the discussion forum disability and the Post 2015 development goal agenda [115] "stated clearly that capacity building of disabled people is also needed so they could hold their own in other discourses" [108]. Capacity building does not only include the need for increasing the level of education of disabled people which is low in many places $[116,117]$ but also the capacity to obtain resources such as employment, health care, social and legal support systems [116] and the capacity to partake in social and political processes which remains an ongoing problem $[108,116,118,119]$.

We posit that the capacity building of disabled people should be a main focus of science, technology and innovation governance discourses. Science education is one of the eight dimensions of responsible innovation as identified by the European Commission [36]. We also posit the need for science policy education and science governance education.

Further, anticipatory is one attribute put forward in many governance discourses. While necessary, the attribute of anticipatory raises particular questions for disabled people [110]: Who has the ability to know early enough that one has to be informed so that one can influence the anticipatory governance discourse of, in this case, gene editing, before the trajectory is set? Gene editing has been discussed for some time but very few disability studies scholars and disability rights advocates and no disability rights groups are involved in gene editing discussions. How will these disability groups that focus on improving the social situation of disabled people know what to advocate for within science, technology and innovation in a timely manner? More specifically, how are they to know that they have to advocate for being part of a given discourse? How are they to know which developments in the area of science, 
technology and innovation will require attention? Does the move from governance to anticipatory governance help, or does it make the situation more problematic? We posit that the concept and dynamic of anticipatory governance generates the need for a watchdog employed by disability rights groups to alert them when they may need to get involved. We posit that if anticipatory governance is to be of use to disability rights groups they have to perform anticipatory advocacy, in order to be part of anticipatory governance discourses that impact their social situation. We define the concept and practice of anticipatory advocacy as an approach to lobby for one's involvement at the forefront of emerging discourses, discussions, and decision making processes of social policies affecting one's well-being. Advocacy efforts within the disability rights community have been advantageous to the enhancement of empowerment and confidence for individuals and groups [120]. As with anticipatory governance in order to be able to perform anticipatory advocacy one has to have the capacity and knowledge in order to participate in an effective and meaningful way which many disabled rights groups are lacking. As science, technology and innovation is changing constantly, disability rights groups will need a sustainable mechanism that allows for the constant upgrade of knowledge in order to be able to anticipate issues and be able to advocate in an anticipatory way to be part of anticipatory governance discourses. A lot of work remains to be done to make the needed meaningful inclusion of disabled people in science, technology and innovation governance discourses a sustainable reality.

\section{Precision Genetic Interventions and Legal Instruments}

If the disability rights angle is not part of the debate, could the UNCRPD or legal instruments covering genetic interventions be used to prevent negative impacts of precision gene interventions and the debates around precision gene interventions on the social situation of disabled people?

\subsection{Precision Genetic Interventions, Legal Instruments and Disabled People: The Role of the UNCRPD}

On the webpage covering the UNCRPD [121], it is stated that throughout "history, persons with disabilities have been viewed as individuals who require societal protection and evoke sympathy rather than respect. This convention is a major step toward changing the perception of disability and ensures that societies recognize that all people must be provided with the opportunities to live life to their fullest potential, whatever that may be" [122]. The UNCRPD was adopted on 13 December 2006 by the United Nations and has so far been ratified by 160 Nations [114]. According to the UNCRPD webpage [114], the Convention followed "decades of work by the United Nations to change attitudes and approaches to persons with disabilities. It takes to a new height the movement from viewing persons with disabilities as 'objects' of charity, medical treatment and social protection towards viewing persons with disabilities as 'subjects' with rights, who are capable of claiming those rights and making decisions for their lives based on their free and informed consent as well as being active members of society" [114].

Given the premise of the UNCRPD, how applicable is the UNCRPD to gene editing interventions and their consequences? In principle, the UNCRPD could intersect with gene editing on two levels; one level being the actual use of gene editing procedures and the second level being about minimizing negative societal consequences for disabled people in the wake of deploying gene editing. If the UNCRPD can be applied to the use of gene editing, the question arises which areas of applications the UNCRPD could be applied to given that gene editing can be applied to born humans, fetuses and embryos and for building genomes from the base pair level up. In Section 3.1.1, we engage with the question of the applicability of the UNCRPD to various gene editing interventions such as gene editing on the level of born humans, fetuses and embryos and for building genomes from the base pair level up. In Section 3.1.2, we discuss the utility of the UNCRPD using the case study of discussions around Genetic Non-Discrimination laws linked to the prevention of discriminatory use of genetic information for insurance and employment purposes. In Section 3.1.3, we discuss the issue of genetic enhancement. 


\subsubsection{The UNCRPD and Various Gene Editing Interventions}

One important question that arises is whether the UNCRPD could be applied to the building of genomes from the base pair level up, gene editing interventions at the pre-birth stage such as genetic modification of the embryo or fetus, or whether the UNCRPD only applies to genetic modification interventions performed after birth? So far, no literature exists that addresses this question. What does exist is a discourse around the topic of whether UNCRPD Articles 10 (right to life), 23 (respect for home and the family) or 25 (health) are applicable to pre-birth actions, more specifically whether the UNCRPD can be used to question the termination of a pregnancy based on a perceived impairment of the fetus [123].

Petersen's article outlined the history around the language debate of Articles 10, 23 and 25 during the drafting of the UNCRPD highlighting that there was an initial desire to use language that covered pre-birth interventions but in the end was rejected. However, Petersen noted that the debate around pre-birth interventions emerged at the international reporting process whereby Petersen used Spain and Hungary as case studies and outlined the actions of the United Nations Committee on the Rights of Persons with Disabilities, which is a panel of independent disability rights experts that oversees the international reporting process for the UNCRPD [123]. An alternative report to Spain's Initial Report on the implementation of the UNCPD written by the Comite Español de Representantes de Personas con Discapacidad highlighted the 2010 law on abortion and used the term "eugenic abortion" to describe abortions that are authorized on the basis of fetal impairment [123]. Petersen stated that "the Committee implicitly categorized a law that makes it easier to terminate a pregnancy in cases of fetal impairment as discriminatory" but also highlighted that the Spanish government in their response "reminded the Committee that the UNCRPD does not require a government to protect life before birth" [123]. Ultimately, the Committee's Concluding Observations on Spain's Initial Report recommended "that the State party abolish the distinction made in Act 2/2010 in the period allowed under law within which a pregnancy can be terminated based solely on disability" [123].

Petersen highlighted further the similar case of the country of Hungary and concluded: "It appears that the Committee is implicitly taking the position that a fetus enjoys rights under the UNCRPD, despite the lack of any explicit statement to this effect in the treaty" and that this seems to be a "departure from the predominant approach in international law, which has traditionally not provided for fetal rights in human rights treaties but rather allowed each individual state to determine whether a fetus enjoys legal rights within that state's domestic legal system" [123].

Interestingly, Petersen outlined further developments in Spain which indicated that the Committee's views were used to push limits on abortion in general but it was not used to end the discrimination based on "impairment" which we posit is not in sync with the views of the Committee and a misuse of the intent of the Committee. The Committee did not question abortion as such.

The Committee's views indicated a concern with pre-birth discriminatory acts evident by treating an "impaired" fetus different than a "non-impaired" fetus by giving protection to the "non-impaired" versus "impaired" fetus. The Committee was focusing on differential legal treatments of when an abortion of an "impaired" and "non-impaired" fetus can take place. The views of the Committee could be applied also to question any demand for sex-selection prohibition if it is not also accompanied by the prohibition of selection based on impairment. However to be clear the Committee's view can only be used to question differential treatment of the fetus based on characteristics and not to question abortion in general. Given that the Committee questions discriminatory acts happening before birth the view of the Committee could also be used to question laws that have a differential treatment of an embryo based on whether its labelled as having an "impairment" or not. In Canada for example Article 5e of the Assisted Human Reproduction Act [124] allow for the deselection of an embryo based on anticipated "impairment/disease" of that embryo but the act does not allow a deselection based on the sex of the embryo. Again, the Committee's views could not be used to prohibit deselection of embryos in general; but just discriminatory acts based on in this case the "impairment" of the embryo. 
The discussion of whether the UNCRPD is applicable to the pre-birth or after birth stage does not tell us whether the UNCRPD can be used to question gene editing interventions in general. On one level, one might be able to argue that the UNCRPD could be used to question a framework of gene editing interventions (pre-birth or after birth) that focuses solely on "fixing" impairments given the anti-discrimination focus of the CRPD. In this case, however, the UNCRPD could not be used to question gene editing interventions if any gene is fair game for modifications, or if we allow gene modification for any reason including genetic enhancement, Furthermore, it is unclear whether the UNCRPD will protect against "curative" interventions. Article 17 of the UNCRPD may be used to question involuntary treatments of a "competent" adult however if parents agree to have genetic interventions performed on their child or if adults with "impairments" agree to genetic interventions the UNCRPD will very likely not apply at all. If the UNCRPD applies it will only apply in ways the UNCRPD applies to curative medicine in general. Finally, we cannot see the UNCRPD being applied to the synthesis of genomes as this area will be about generating new gene products and not only about avoiding "impairments".

To recap, we posit that it is rather unclear whether the UNCRPD can be and will be applied to question the actual use of gene editing procedures. However, the UNCRDP might be used to minimize negative societal consequences for disabled people in the wake of deploying gene editing. This could include in the future people who will be defined as impaired and disabled due to not being enhanced in case genetic enhancement procedures will be performed.

\subsubsection{UNCRPD and the Discriminatory Use of Genetic Information in the Workplace}

Various articles thematized the issue of genetic discrimination in relation to pre-birth genetic testing $[80,90-92,105,125,126]$, an area already covered in this essay. However, genetic discrimination also exists in after birth settings such as the use of genetic information in areas such as employment and insurance [127-134]. Various international agreements have thematized how to deal with genetic information: Article 6 of the Universal Declaration on the Human Genome and Human Rights of UNESCO states that "[n]o one shall be subject to discrimination based on genetic characteristics that is intended to infringe or has the effect of infringing human rights, fundamental freedoms and human dignity". The European Convention for the Protection of Human Rights and Dignity of the Human Being declares in Article 11 on Non-Discrimination that "[a]ny form of discrimination against a person on grounds of his or her genetic heritage is prohibited". The Draft World Health Organization (WHO) guidelines on bioethics states: "Genetic information should not be used as the basis for refusing employment or insurance. Exceptions would have to be legally defined" [135].

To engage with the discourse around the discriminatory use of genetic information in areas such as employment and insurance, we look at three legal instruments; the first being the US Genetic Information Non-discrimination Act (GINA) which was one of the first National Genetic Non-Discrimination Acts to be discussed. GINA can be seen to be discriminatory against disabled people in the sense that its scope is at the asymptomatic state of "impairment" [128]. In other words, if one has a genetic make-up that might lead to an "impairment" one is only protected against genetic discrimination until one exhibits the "impairment". The American Civil Liberties Union (ACLU) in its campaign for a law prohibiting genetic discrimination supported this difference when they stated: "that Congress should take immediate steps to protect genetic privacy...[because] it is inherently unfair to discriminate against someone based on immutable characteristics that do not limit their abilities" [128]. In a congressional hearing back in 2001, the following was stated on behalf of the ACLU:

In addition to establishing the privacy of genetic information, federal law should prohibit discrimination in employment or insurance based on genetic information. There are three reasons why Congress should take immediate steps to prohibit the use of such information by employers or insurers: First, it is inherently unfair to discriminate against someone based on immutable characteristics that do not affect their ability to perform a job; Second, the mere fact that someone has a genetic predisposition to a health condition is 
an unreliable basis to act on the risk that he or she will actually develop that condition in the future. Genetic tests do not show with certainty that any individual will eventually develop a disease or how severe their symptoms might be, and third, the threat of genetic discrimination leads individuals to decline genetic screenings and other health services to avoid revealing information that may be used against them [136].

The National Council on Disability (NCD) of the United States questioned the segregation between symptomatic and asymptomatic individuals [137]. It was seen as preferable by disability rights groups in the USA involved in the discussions around GINA that GINA should have provided protection for disabled people whether they are symptomatic or asymptomatic [128]. Although employment discrimination can be dealt with in the USA through other legal instruments [129] such as the American with Disabilities Act (ADA) $[136,138,139]$, this approach was seen as problematic [139]. Although groups like the National Council on Disability had questioned the asymptomatic limitation of GINA, the law was enacted in 2008 with the same provision [140].

One might be able to make a case that GINA is in violation of Article 27-Work and employment of the UNCRPD—especially if one could make a case that GINA covering disabled people might lead to better outcomes for the employment of disabled people than if disabled people are just covered under the ADA. However independent of whether one can make a case that GINA violates Article 27 of the UNCRPD in the moment this is a moot point as the USA has not ratified the UNCRPD yet.

As to the second example, the Canadian Parliament is currently debating a proposal for a Genetic Anti-Discrimination Act [141]. This bill is equated to the GINA in a sense that it also focuses on asymptomatic people. The Act states "This enactment prohibits any person from requiring an individual to undergo a genetic test or disclose the results of a genetic test as a condition of providing goods or services to, entering into or continuing a contract or agreement with, or offering specific conditions in a contract or agreement with, the individual" [141]. It states further: "The enactment amends the Canada Labour Code to protect employees from being required to undergo or to disclose the results of a genetic test, and provides employees with other protections related to genetic testing and test results. It also amends the Canadian Human Rights Act to prohibit discrimination on the ground of genetic characteristics" [141]. Section 2 of the Canadian Human Rights Act is to be replaced by the following list of prohibited discriminations: "discriminatory practices based on race, national or ethnic origin, colour, religion, age, sex, sexual orientation, marital status, family status, genetic characteristics, disability or conviction for an offence for which a pardon has been granted or in respect of which a record suspension has been ordered" [141].

This list suggests that genetic characteristics are not part of disability or in other words that genetic characteristics are not covered under disability or vice versa. The bill does not mention the UNCRPD and how it could intertwine with the bill. That genetic characteristics are now listed besides disability could open the door for the suggestion that the UNCRPD, which Canada ratified, might not be applicable to the area of genetic characteristics. It could also mean that genetic characteristic is purely seen to cover asymptomatic people and disability is seen to cover symptomatic people. So far it is unclear what the wording means in relation to the UNCRPD. Interestingly, disability rights groups in Canada were not involved in the discussion around this bill. This may be because the Act defines genetic discrimination as "occur[ing] when people are treated unfairly because of actual or perceived differences in their genetic information that may cause or increase the risk to develop a disorder or disease" [142]. Although the UNCRPD is seen to cover future "disabilities" [143], the groups involved did not employ the UNCRPD but rather pushed for a law separate from disability related legislation.. Malhotra envisioned that the UNCRPD will be used in Canada eventually [144]. The discussion around genetic discrimination could have been such a case and as such could be seen as a lost opportunity for the UNCRPD.

As to the third example, DePaor and Ferris covered the "scope for an EU to effectively address genetic discrimination and the misuse of genetic information" [134] and how the UNCRPD would impact employment based genetic discrimination [134]. They concluded that although "genetic features 
is a missing ground in the Employment Equality Directive" it could be covered under disability. They stated "The Employment Equality Directive could accordingly cover under 'disability discrimination' and any other discrimination on the ground of the prediction of future illness or future loss of functions in a currently asymptomatic individual or on the ground of a genetic susceptibility to future health problems" [134]. They noted that the Employment Equality Directive had no definition of disability and as such there was no barrier to such broad interpretation but indeed that such a broad definition would be in sync with the UNCRPD [134].

They argued that the Court of Justice of the European Union, in the cases of Ring and Werge, which were in essence about the need for guidance as to what is seen to be a disability in regard to Directive 2000/78 [145] distanced itself from their position it took in the Chacon Navas case which defined disability in a very narrow way toward a position that followed the UNCRPD Article 1 definition of disability [134] (see also [146]). They argued that "the particular cases of Ring and Werge and Commission v. Italy leave the door open for the wide interpretation of the Employment Equality Directive in light of the UNCRPD to also cover genetic discrimination in the field of employment under disability discrimination" [134]. However, so far the UNCRPD has not been applied to genetic discrimination related to employment.

Interestingly, Green suggests that "the notion of immutable genetic risks may become obsolete, and it may be less important to grant genetic information special protection than to protect everyone from all forms of medical discrimination. As all medicine in a sense becomes genomic medicine, perhaps the genetic nondiscrimination secured by GINA will translate into nondiscrimination in all of medicine" [140].

\subsubsection{Genetic Enhancement}

Finally, genetic enhancement is one aspect discussed around gene editing whereby one can make a case that various areas covered by the UNCRPD are impacted by the act of human enhancements [147-149]. The UNCRPD could be applied to any worsening of the situation for disabled people linked to disabled people's lack of access to enhancements. Given that the UNCRPD sees disability as an evolving concept and that future "disability" is covered under disability, the UNCRPD might also apply to people who are seen at the moment as non-impaired but who will be classified as impaired, as disabled, down the road because they cannot keep up with changing ability expectations due to genetic and technological enhancements of humans. It will be interesting whether the UNCRPD will be used to demand access to enhancement products and procedures and whether access to enhancement products and procedures will be seen as a reasonable accommodation.

The UNCRPD is one legal instrument that could play a role in preventing a worsening of the social situation of disabled people in the wake of gene editing. Genetic related legal instruments are another set of documents that could have utility in regards to preventing negative consequences for disabled people.

\subsection{Precision Genetic Interventions, Legal Instruments and Disabled People: The Role of Genetic Related Legal Instruments}

Various international agreements such as UNESCO's Universal Declaration on the Human Genome and Human Rights [150], the Convention for the Protection of Human Rights and Dignity of the Human Being with regard to the Application of Biology and Medicine: Convention on Human Rights and Biomedicine [37] and UNESCO's International Declaration on Human Genetic Data [151] contain language which could be applied to disabled people.

\subsubsection{UNESCO's Universal Declaration on the Human Genome and Human Rights}

Various articles of the UNESCO's Universal Declaration on the Human Genome and Human Rights [150] could be applied to disabled people. For example, Article 11-Non-discrimination and non-stigmatization states: “No individual or group should be discriminated against or stigmatized 
on any grounds, in violation of human dignity, human rights and fundamental freedoms" [150]; Article 13-Solidarity and cooperation states: "Solidarity among human beings and international cooperation towards that end are to be encouraged" [150]; Article 14-Social responsibility and health section d states: "elimination of the marginalization and the exclusion of persons on the basis of any grounds" [150]; and Article 20-Risk assessment and management states: "Appropriate assessment and adequate management of risk related to medicine, life sciences and associated technologies should be promoted" [150]. However the applicability of the language might be limited by Article 27-Limitations on the application of the principles which states: "If the application of the principles of this Declaration is to be limited, it should be by law, including laws in the interests of public safety, for the investigation, detection and prosecution of criminal offences, for the protection of public health or for the protection of the rights and freedoms of others. Any such law needs to be consistent with international human rights law" [150]. Given the statement of Article 27, it is not clear how disabled people with a disability rights approach would fare within the frameworks of public health (obligation to let oneself be fixed) and the protection of the rights and freedoms of others (caregivers and others could be seen to be impacted by the disability rights approach).

3.2.2. Convention for the Protection of Human Rights and Dignity of the Human Being with Regard to the Application of Biology and Medicine: Convention on Human Rights and Biomedicine

The Convention for the Protection of Human Rights and Dignity of the Human Being with regard to the Application of Biology and Medicine: Convention on Human Rights and Biomedicine [37] also highlights the internal inconsistencies of the language used and the limitations of the language applicable to disabled people. For example, Article 11-Non-discrimination states: "Any form of discrimination against a person on grounds of his or her genetic heritage is prohibited" [37]. But how does Article 11 fit with Article 14-Non-selection of sex which states: "The use of techniques of medically assisted procreation shall not be allowed for the purpose of choosing a future child's sex, except where serious hereditary sex-related disease is to be avoided" [37]. Interpreting this, Article 14 is promoting discrimination based on genetic heritage at the pre-birth stage since one can select against sex-related disease. As such, Article 14 might go against the United Nations Committee on the Rights of Persons with Disabilities interpretation of the UNCRPD (see Section 3.1.1).

\subsection{UNESCO's International Declaration on Human Genetic Data}

UNESCO's International Declaration on Human Genetic Data [151] states in Article 3-Person's identity that "[e]ach individual has a characteristic genetic make-up. Nevertheless, a person's identity should not be reduced to genetic characteristics, since it involves complex educational, environmental and personal factors and emotional, social, spiritual and cultural bonds with others and implies a dimension of freedom" [151]. And Article 7-Non-discrimination and non-stigmatization states: “(a) Every effort should be made to ensure that human genetic data and human proteomic data are not used for purposes that discriminate in a way that is intended to infringe, or has the effect of infringing human rights, fundamental freedoms or human dignity of an individual or for purposes that lead to the stigmatization of an individual, a family, a group or communities" [151].

Both Article 3 and Article 7 could be used to support the disability rights message that the focus should be less on labelling a body as defective and more about acceptance of diversity and the elimination of social problems ability different people face. However, the UNESCO document has not been deployed by disability rights groups to make their case.

\subsection{Further Thoughts}

The statement of the International Summit on Human Gene Editing acknowledges that "while each nation ultimately has the authority to regulate activities under its jurisdiction, the human genome is shared among all nations. The international community should strive to establish norms concerning acceptable uses of human germline editing and to harmonize regulations, in order to discourage 
unacceptable activities while advancing human health and welfare" [21]. However, laws, frameworks and regulations each reflect different levels of acceptance for different applications [23] so the question is which gene editing applications will be seen as problematic and whether a global consensus of prohibition will emerge?

It is not clear from the Summit statement of the International Summit on Human Gene Editing which gene editing applications will be prohibited in the end. Indeed it suggests that little will be prohibited if anything. Furthermore, it is not clear what any prohibitions will mean for disabled people currently and in the future. If laws make a distinction based on the disease label, the laws will not protect disabled people.

One of the commissioned papers for the International Summit on Human Gene Editing lists five levels of restrictions for proceeding with germline interventions with the second highest level being "Hold off (place a moratorium) on editing the human germline genome for reproduction at least until we (re)frame and make much more inclusive vital ethical, social, and economic debates around ableism and disability justice, the over medicalization of human variability, racism and sexism in science, local and global health inequality, the views of non-stakeholders as well as stakeholders, and the needs of future generations, the vulnerable, and other species" [74]. So far, there is no indication that this level of restriction will be followed.

\section{Conclusions}

The ability to perform precision genetic interventions on the somatic and germline level is ever increasing. So far, the perspective of disability groups and individuals that focus on improving the social situation of disabled people does not have a voice or influence on the strategies around how to sell or question genetic interventions on the somatic and germline level. Although some posit that the UNCRPD could be applied to deal with workplace related genetic discrimination [134], it is unclear to what extent the UNCRPD will be applicable with regards to gene editing actions. International agreements covering genetics have not been used so far to support a disability rights argument. It seems that until one has a way of gaining support for questioning the underlying ability expectation oppression that exists in the gene editing discourses and to gain support for a focus on ability expectation governance $[1,152]$, the discourse as is will end with the acceptance of somatic and germline genetic interventions including somatic and germline genetic enhancements and genomic synthesis and design.

Author Contributions: G.W. conceptualized the project. G.W. and L.D. researched and wrote the article. All authors read and approved the final manuscript.

Conflicts of Interest: The authors declare no conflict of interest.

\section{References}

1. Wolbring, Gregor. “Gene editing: Govern ability expectations.” Nature 527 (2015): 446. [CrossRef] [PubMed]

2. Wolbring, Gregor. "Let's talk about the ethics of germline modification." In Impactethics. Halifax: Dalhousie University, 2015.

3. McRuer, Robert, and Merri Johnson. "Proliferating cripistemologies." Journal of Literary E Cultural Disability Studies 8 (2014): 149-70. [CrossRef]

4. Goodley, Dan. “Dis/entangling critical disability studies.” Disability E Society 28 (2012): 631-44. [CrossRef]

5. Goodley, Dan. Dis/ability Studies: Theorising Disablism and Ableism. London and New York: Routledge, 2014.

6. Barnes, Colin. “Disability studies: New or not so new directions?" Disability E Society 14 (1999): 577-80. [CrossRef]

7. Garland-Thomson, Rosemarie. "Disability and social theory: New developments and directions." Disability $\mathcal{E}$ Society 29 (2014): 664-66. [CrossRef]

8. Campbell, Jane, and Mike Oliver. Disability Politics: Understanding Our Past, Changing Our Future. London and New York: Routledge, 2013. 
9. Vehmas, Simo, and Nick Watson. "Moral wrongs, disadvantages, and disability: A critique of critical disability studies." Disability \& Society 29 (2014): 638-50. [CrossRef]

10. Shakespeare, Tom. Disability Research Today: International Perspectives. London and New York: Routledge, 2015.

11. Koch, Tom. "Disability and difference: Balancing social and physical constructions." Journal of Medical Ethics 27 (2001): 370-76. [CrossRef] [PubMed]

12. Mathews, Debra J. H., and Robin Lovell-Badge. “A path through the thicket." Nature 527 (2015): $159-61$. [CrossRef] [PubMed]

13. Lanphier, Edward, Fyodor Urnov, Sarah Ehlen Haecker, Michael Werner, and Joanna Smolenski. “Don't edit the human germ line." Nature 519 (2015): 410. [CrossRef] [PubMed]

14. Liang, Puping, Yanwen Xu, Xiya Zhang, Chenhui Ding, Rui Huang, Zhen Zhang, Jie Lv, Xiaowei Xie, Yuxi Chen, and Yujing Li. "CRISPR/Cas9-mediated gene editing in human tripronuclear zygotes." Protein \& Cell 6 (2015): 363-72. [CrossRef] [PubMed]

15. Carroll, Dana, and R. Alta Charo. "The societal opportunities and challenges of genome editing." Genome Biology 16 (2015): 1-9. [CrossRef] [PubMed]

16. Smolenski, Joanna. "CRISPR/Cas9 and germline modification: New difficulties in obtaining informed consent." The American Journal of Bioethics 15 (2015): 35-37. [CrossRef] [PubMed]

17. Pepper, Michael Sean, Coutinho Gouveia, and Melodie Slabbert. "Legislation governing pluripotent stem cells in South Africa." South African Journal of Bioethics and Law 8 (2015): 23-31. [CrossRef]

18. Caplan, Arthur L., Brendan Parent, Michael Shen, and Carolyn Plunkett. "No time to waste-The ethical challenges created by crispr." EMBO Reports 16 (2015): 1421-26. [CrossRef] [PubMed]

19. Chang, Michele C. Y., and Huimin Zhao. "Editorial overview: Opportunities and challenges in synthetic biology." Current Opinion in Chemical Biology 28 (2015): 5-6. [CrossRef] [PubMed]

20. Andrianantoandro, Ernesto. "Manifesting synthetic biology." Trends in Biotechnology 33 (2015): 55-56. [CrossRef] [PubMed]

21. Organizing Committee for the International Summit on Human Gene Editing. "On human gene editing: International summit statement." Available online: http://www8.nationalacademies.org/onpinews/ newsitem.aspx?RecordID=12032015a (accessed on 25 August 2016).

22. Green, Ronald M. “Designer babies." 2015. Available online: http://ic.galegroup.com/ic/scic/ ReferenceDetailsPage/ReferenceDetailsWindow? failOverType=\&query=\&prodId=SCIC\&windowstate= normal\&contentModules $=\&$ display-query $=\&$ mode $=$ view $\&$ displayGroupName=Reference\&limiter $=$ \&currPage=\&disableHighlighting=false\&displayGroups=\&sortBy=\&search_within_results $=\& p=S C I C \&$ action=e\&catId=\&activityType=\&scanId=\&documentId=GALE $\backslash$ T1 $\backslash$ textbar \{\} XAPYSP810662464\&source= Bookmark\&u=ko_k12hs_d66\&jsid=49ba29e592a55913f082aef5a6e3ba33 (accessed on 25 August 2016).

23. Chan, Sarah, Peter J. Donovan, Thomas Douglas, Christopher Gyngell, John Harris, Robin Lovell-Badge, Debra J. H. Mathews, Alan Regenberg, and Hinxton Group. "Genome editing technologies and human germline genetic modification: The hinxton group consensus statement." The American Journal of Bioethics 15 (2015): 42-47. [CrossRef] [PubMed]

24. Adashi, Eli Y., and I. Glenn Cohen. "Editing the genome of the human germline: May cool heads prevail." The American Journal of Bioethics 15 (2015): 40-42. [CrossRef] [PubMed]

25. Ishii, Tetsuya. "Germ line genome editing in clinics: The approaches, objectives and global society." Briefings in Functional Genomics, 2015. [CrossRef] [PubMed]

26. Lundberg, Ante S., and Rodger Novak. "CRISPR-Cas gene editing to cure serious diseases: Treat the patient, not the germ line." The American Journal of Bioethics 15 (2015): 38-40. [CrossRef] [PubMed]

27. Ishii, Tetsuya. "Germline genome-editing research and its socioethical implications." Trends in Molecular Medicine 21 (2015): 473-81. [CrossRef] [PubMed]

28. Sugarman, Jeremy. "Ethics and germline gene editing." EMBO Reports 16 (2015): 879-80. [CrossRef] [PubMed]

29. Bosley, Katrine S., Michael Botchan, Annelien L. Bredenoord, Dana Carroll, R. Alta Charo, Emmanuelle Charpentier, Ron Cohen, Jacob Corn, Jennifer Doudna, and Guoping Feng. "CRISPR germline engineering-The community speaks." Nature Biotechnology 33 (2015): 478-86. [CrossRef] [PubMed]

30. King, Anthony. "Gene editing fears." 2015. Available online: http://www.soci.org/chemistry-and-industry/ cni-data/2015/11/gene-editing-fears (accessed on 25 August 2016). 
31. Reich, Jens, Heiner Fangerau, Boris Fehse, Jürgen Hampel, Ferdinand Hucho, Kristian Köchy, Martin Korte, Bernd Müller-Röber, Jochen Taupitz, and Jörn Walter. Human Genome Surgery-Towards a Responsible Evaluation of a New Technology. Analysis by the Interdisciplinary Research Group Gene Technology Report. Berlin: Berlin-Brandenburg Academy of Sciences and Humanities, 2015.

32. Wender, Benjamin A., Rider W. Foley, David H. Guston, Thomas P. Seager, and Armin Wiek. "Anticipatory governance and anticipatory life cycle assessment of single wall carbon nanotube anode lithium ion batteries." Nanotechnology Law \& Business 9 (2012): 201-16.

33. Guston, David. “The anticipatory governance of emerging technologies." Journal of Korean Vacuum Society 19 (2010): 432-41. [CrossRef]

34. Guston, David H. “Understanding 'anticipatory governance'." Social Studies of Science 44 (2014): $218-42$. [CrossRef] [PubMed]

35. Von Schomberg, Rene. "Prospects for technology assessment in a framework of responsible research and innovation." In Technikfolgen Abschätzen Lehren: Bildungspotenziale Transdisziplinärer Methoden. Edited by Richard Beecroft and Marc Dusseldorp. Wiesbaden: VS Verlag, 2012, pp. 39-61.

36. Expert Group on Policy Indicators for Responsible Research and Innovation of the European Commission. "Indicators for promoting and monitoring responsible research and innovation." Available online: http://ec. europa.eu/research/swafs/pdf/pub_rri/rri_indicators_final_version.pdf (accessed on 25 August 2016).

37. European Community. "Convention for the protection of human rights and dignity of the human being with regard to the application of biology and medicine: Convention on human rights and biomedicine." Available online: http:/ / conventions.coe.int/Treaty/en/Treaties/Html/164.htm (accessed on 25 August 2016).

38. Wilsdon, James, and Rebecca Willis. See-Through Science: Why Public Engagement Needs to Move Upstream. London: Demos, 2004.

39. Hansen, Janus. Biotechnology and Public Engagement in Europe. London: Palgrave Macmillan, 2010.

40. Plows, Alexandra, and Michael Reinsborough. "Nanobiotechnology and ethics: Converging civil society discourses." In Emerging Conceptual, Ethical and Policy Issues in Bionanotechnology. Birlin: Springer, 2008, pp. 133-56.

41. Flear, Mark L., and Martyn D. Pickersgill. “Regulatory or regulating publics? The european union's regulation of emerging health technologies and citizen participation." Medical Law Review 21 (2013): 39-70. [CrossRef] [PubMed]

42. Dijkstra, Anne M., and Mirjam Schuijff. "Public opinions about human enhancement can enhance the expert-only debate: A review study." Public Understanding of Science, 2015. [CrossRef] [PubMed]

43. Tindana, Paulina, Jantina de Vries, Megan Campbell, Katherine Littler, Janet Seeley, Patricia Marshall, Jennifer Troyer, Morisola Ogundipe, Vincent P. Alibu, and Aminu Yakubu. “Community engagement strategies for genomic studies in africa: A review of the literature." BMC Medical Ethics 16 (2015): 24. [CrossRef] [PubMed]

44. Murphy, Juli, Joan Scott, David Kaufman, Gail Geller, Lisa LeRoy, and Kathy Hudson. "Public expectations for return of results from large-cohort genetic research." The American Journal of Bioethics 8 (2008): 36-43. [CrossRef] [PubMed]

45. Fiore, Robin N., and Kenneth W. Goodman. "Precision medicine ethics: Selected issues and developments in next-generation sequencing, clinical oncology, and ethics." Current Opinion in Oncology 28 (2016): 83-87. [CrossRef] [PubMed]

46. Burgess, Michael, Kieran O'Doherty, and David Secko. "Biobanking in British Columbia: Discussions of the future of personalized medicine through deliberative public engagement." Personalized Medicine 5 (2008): 285-96. [CrossRef]

47. Stacey Kuznetsov, Aniket Kittur, and Eric Paulos. "Biological citizen publics: Personal genetics as a site of public engagement with science." Paper presented at the 2015 ACM SIGCHI Conference on Creativity and Cognition, Glasgow, UK, 22-25 June 2015, pp. 303-12.

48. Coutelle, Charles, and Richard Ashcroft. "Risks, benefits and ethical, legal, and societal considerations for translation of prenatal gene therapy to human application." In Prenatal Gene Therapy. New York: Springer, 2012, pp. 371-87.

49. Douglas, Conor M. W., and Dirk Stemerding. “Governing synthetic biology for global health through responsible research and innovation." Systems and Synthetic Biology 7 (2013): 139-50. [CrossRef] [PubMed] 
50. Marris, Claire. "The construction of imaginaries of the public as a threat to synthetic biology." Science as Culture 24 (2015): 83-98. [CrossRef]

51. Brossard, Dominique. "Scientists and synthetic biology: New science, new media, (new) public engagement." Paper presented at the 2016 AAAS Annual Meeting, Washington, DC, USA, 11-15 February 2016.

52. Kouper, Inna. "A critical participatory approach to the evaluation of synthetic biology." In Ambivalences of Creating Life. Cham: Springer, 2016, pp. 215-41.

53. Dove, Edward S., and Vural Özdemir. "What role for law, human rights, and bioethics in an age of big data, consortia science, and consortia ethics? The importance of trustworthiness." Laws 4 (2015): 515-40. [CrossRef] [PubMed]

54. Mirnezami, Reza, Jeremy Nicholson, and Ara Darzi. "Preparing for precision medicine." New England Journal of Medicine 366 (2012): 489-91. [CrossRef] [PubMed]

55. Church of Scotland. "Moral and ethical issues in gene therapy." Available online: http:/ /www.srtp.org.uk/ srtp/view_article/moral_and_ethical_issues_gene_therapy (accessed on 25 August 2016).

56. Olson, Steven. "International summit on human gene editing: A global discussion." Available online: http:// www.nap.edu/catalog/21913/international-summit-on-human-gene-editing-a-global-discussion (accessed on 25 August 2016).

57. Wolbring, Gregor. "Solutions follow perception: Nano-bio-info-cogno-technology (NBIC) and the concept of health, medicine, disability and disease." Alberta Health Law Review 12 (2004): 41-47. [PubMed]

58. Wolbring, Gregor. "HTA Initiative \#23 the Triangle of Enhancement Medicine, Disabled People, and the Concept of Health: A new Challenge for Hta, Health Research, and Health Policy." Alberta Heritage Foundation for Medical Research (AHFMR), 2005. Available online: http://www.ihe.ca/documents/HTA-FR23.pdf (accessed on 25 August 2016).

59. Wolbring, Gregor. Nanotechnology and the Transhumanization of Health, Medicine, and Rehabilitation. Edited by Daniel Lee Kleinmann, Jason Delborne, Karen A. Cloud-Hansen and Jo Handelsman. New Rochelle: Mary Ann Liebert, 2010, pp. 290-303.

60. Wolbring, Gregor. "Glossary for the 21st century." International Center for Bioethics, Culture and Disability, 2009. Available online: http:/ / www.bioethicsanddisability.org/glossary.htm (accessed on 25 August 2016).

61. Wolbring, Gregor. "Science and technology and the triple D (disease, disability, defect)." In Converging Technologies for Improving Human Performance: Nanotechnology, Biotechnology, Information Technology and Cognitive Science. Edited by Mihail C. Roco and William Sims Bainbridge. Dordrecht: Kluwer Academic, 2003, pp. 232-43.

62. Zeng, Fang-Gang. "Cochlear implants in China." Audiology 34 (1995): 61-75. [CrossRef] [PubMed]

63. Hladek, Glenn A. "Cochlear implants, the deaf culture, and ethics: A study of disability, informed surrogate consent, and ethnocide." Monash Bioethics Review 21 (2002): 29-44. [CrossRef] [PubMed]

64. Blume, Stuart S. The Artificial Ear: Cochlear Implants and the Culture of Deafness. New Brunswick: Rutgers University Press, 2010.

65. Wolbring, Gregor. "Hearing beyond the normal enabled by therapeutic devices: The role of the recipient and the hearing profession." Neuroethics 6 (2011): 607-16. [CrossRef] [PubMed]

66. Trivedi, Bijal. "Autistic and proud." New Scientist 186 (2005): 36-40.

67. Jurecic, Ann. "Neurodiversity." College English 69 (2007): 421-42.

68. Jaarsma, Pier, and Stellan Welin. "Autism as a natural human variation: Reflections on the claims of the neurodiversity movement." Health Care Analysis 20 (2012): 20-30. [CrossRef] [PubMed]

69. Kapp, Steven K., Kristen Gillespie-Lynch, Lauren E. Sherman, and Ted Hutman. "Deficit, difference, or both? Autism and neurodiversity." Developmental Psychology 49 (2013): 59-71. [CrossRef] [PubMed]

70. Wolbring, Gregor. "Culture of peace' from an ability and disability studies lens." In Expanding Peace Ecology: Peace, Security, Sustainability, Equity and Gender, Perspectives of IPRA's Ecology and Peace Commission. Edited by Ursula Oswald Spring, Hans Günter Brauch and Keith Tidball. New York: Springer, 2013, vol. 12, p. 193.

71. Harris, John. "Is there a coherent social conception of disability? " Journal of Medical Ethics 26 (2000): 95-100. [CrossRef] [PubMed]

72. Reindal, Solveig M. "Disability, gene therapy and eugenics-A challenge to John Harris." Journal of Medical Ethics 26 (2000): 89-94. [CrossRef] [PubMed]

73. Harris, John. "One principle and three fallacies of disability studies." Journal of Medical Ethics 27 (2001): 383-87. [CrossRef] [PubMed] 
74. Chinese Academy of Sciences, the Royal Society, U.S. National Academy of Sciences, and U.S. National Academy of Medicine. "International summit on human gene editing commissioned papers." Available online: http://www.nationalacademies.org/cs/groups/pgasite/documents/webpage/pga_170455.pdf (accessed on 25 August 2016).

75. Asch, Adrienne. "Disability equality and prenatal testing: Contradictory or compatible." Florida State University Law Review 30 (2002): 315-42.

76. Groce, Nora Ellen, and Jonathan Marks. “The great ape project and disability rights: Ominous undercurrents of eugenics in action." American Anthropologist 102 (2000): 818-22. [CrossRef]

77. Shakespeare, Tom. "Disability, genetics and global justice." Social Policy and Society 4 (2005): 87-95. [CrossRef]

78. Kahane, Greg, and Julian Savulescu. "Disability and mere difference." Ethics: An International Journal of Social, Political, and Legal Philosophy 126 (2016): 774-88. [CrossRef]

79. Bognar, Greg. "Is disability mere difference?" Journal of Medical Ethics 42 (2016): 46-49. [CrossRef] [PubMed]

80. Scully, Jackie Leach. "Disability and genetics in the era of genomic medicine." Nature Reviews Genetics 9 (2008): 797-802. [CrossRef] [PubMed]

81. Center for Genetics and Society. "Open letter calls for prohibition on reproductive human germline modification." Available online: http://www.geneticsandsociety.rsvp1.com/article.php?id=8999\&mgh= http\%3A\%2F\%2Fwww.geneticsandsociety.org\&mgf=1 (accessed on 25 August 2016).

82. Boundy, Kathyrn. "'Are you sure, sweetheart, that you want to be well?': An exploration of the neurodiversity movement." Radical Psychology: A Journal of Psychology, Politics E Radicalism 7 (2008): 1-20.

83. Broderick, Alicia A., and Ari Ne'eman. "Autism as metaphor: Narrative and counter-narrative." International Journal of Inclusive Education 12 (2008): 459-76. [CrossRef]

84. Kapp, Steven K. “Navajo and autism: The beauty of harmony." Disability and Society 26 (2011): 583-95. [CrossRef]

85. Aspies for Freedom. "Aspies for freedom." Available online: http://www.aspiesforfreedom.com/ (accessed on 25 August 2016).

86. Norbury, Courtenay Frazier, and Alison Sparks. “Difference or disorder? Cultural issues in understanding neurodevelopmental disorders." Developmental Psychology 49 (2013): 45-48. [CrossRef] [PubMed]

87. Waltz, Mitzi. "Worlds of autism: Across the spectrum of neurological difference." Disability $\mathcal{E}$ Society 29 (2014): 1337-38. [CrossRef]

88. Thibault, Ronnie. "Can autistics redefine autism? The cultural politics of autistic activism." Trans-Scripts 4 (2014): 57-88.

89. Somashekhar, Sandhya. "The new age of autism, neurodiversity movement is helping adults find a sense of community and purpose." The Vancouver Sun, 24 July 2015.

90. Pfeiffer, David. "Eugenics and disability discrimination." Disability and Society 9 (1994): 481-99. [CrossRef]

91. Shakespeare, Tom. "Back to the future? New genetics and disabled people." Critical Social Policy 15 (1995): 22-35. [CrossRef]

92. Ward, Linda M. "Whose right to choose? The'new'genetics, prenatal testing and people with learning difficulties." Critical Public Health 12 (2002): 187-200. [CrossRef]

93. Wolbring, Gregor. "Disability rights approach toward bioethics?" Journal of Disability Policy Studies 14 (2003): 174-80. [CrossRef]

94. Wolbring, Gregor. "The animal farm philosophy of genetic discrimination." Law and the Human Genome Review 21 (2004): 165-84. [PubMed]

95. Willis, Rebecca, and James Wilsdon. See-Through Science. London: Demos, 2004.

96. Parens, Erik, and Adrienne Asch. "The disability rights critique of prenatal genetic testing. Reflections and recommendations." Hastings Center Report 29 (1999): S1-22. [CrossRef] [PubMed]

97. Savulescu, Julian. "Education and debate: Deaf lesbians, 'designer disability,' and the future of medicine." BMJ 325 (2002): 771-73. [CrossRef] [PubMed]

98. Savulescu, Julian, and Guy Kahane. "The moral obligation to create children with the best chance of the best life." Bioethics 23 (2009): 274-90. [CrossRef] [PubMed]

99. Savulescu, Julian. "In defence of procreative beneficence." Journal of Medical Ethics 33 (2007): 284-88. [CrossRef] [PubMed]

100. Sparrow, Robert. "A not-so-new eugenics: Harris and Savulescu on human enhancement." Asian Bioethics Review 2 (2010): 288-307. [CrossRef] 
101. Wolbring, Gregor. "The unenhanced underclass." In Better Humans? The Politics of Human Enhancement. Edited by Paul Miller and James Wilsdon. London: Demos, 2006, pp. 122-29.

102. Wolbring, Gregor. "Is there an end to out-able? Is there an end to the rat race for abilities? "Journal: Media and Culture, 2008. Available online: http:/ /www.journal.media-culture.org.au/index.php/mcjournal/article/ viewArticle/57 (accessed on 25 August 2016).

103. Wolbring, Gregor. "Ableism, enhancement medicine and the techno poor disabled." In Unnatural Selection: The Challenges of Engineering Tomorrow's People. Edited by Peter Healey and Steve Rayner. London: Earthscan, 2008, pp. 196-208.

104. Shakespeare, Tom. “Gene editing: Heed disability views." Nature 527 (2015): 446. [CrossRef] [PubMed]

105. Stowe, Matthew J., H. Rutherford Turnbull, Suzanne Schrandt, and Jennifer Rack. "Looking to the future: Intellectual and developmental disabilities in the genetics era." Journal on Developmental Disabilities 13 (2006): $1-64$.

106. UNESCO. "Unesco world conference on sciences declaration on science and the use of scientific knowledge." Available online: http://www.unesco.org/science/wcs/eng/declaration_e.htm (accessed on 25 August 2016).

107. UNESCO. “Unesco world conference on sciences, science agenda-framework for action." Available online: http:/ /www.unesco.org/science/wcs/eng/framework.htm (accessed on 25 August 2016).

108. Wolbring, Gregor, Rachel Mackay, Theresa Rybchinski, and Jacqueline Noga. "Disabled people and the post-2015 development goal agenda through a disability studies lens." Sustainability 5 (2013): 4152-82. [CrossRef]

109. Yeo, Rebecca, and Karen Moore. "Including disabled people in poverty reduction work: Nothing about us, without us." World Development 31 (2003): 571-90. [CrossRef]

110. Wolbring, Gregor, and Lucy Diep. “Cognitive/neuroenhancement through an ability studies lens." In Cognitive Enhancement. Edited by Fabrice Jotterand and Veljko Dubljevic. Oxford: Oxford University Press, 2016, pp. 57-75.

111. Bureau of Labor Statistics, United States Department of Labor. "Persons with a disability: Labor force characteristics summary." Available online: http:/ /www.bls.gov/news.release/disabl.nr0.htm (accessed on 25 August 2016).

112. Wolbring, Gregor. "Employment, disabled people and robots: What is the narrative in the academic literature and Canadian newspapers?" Societies 6 (2016): 15. [CrossRef]

113. Beresford, Peter. "Poverty and disabled people: Challenging dominant debates and policies." Disability $\mathcal{E}$ Society 11 (1996): 553-68.

114. United Nations. "Convention on the rights of persons with disabilities (CRPD)." Available online: https://www.un.org/development/desa/disabilities/convention-on-the-rights-of-persons-withdisabilities.html (accessed on 25 August 2016).

115. Participants of the UN Department of Economic and Social Affairs (UNDESA) and UNICEF organized Online Consultation-8 March-5 April Disability inclusive development agenda towards 2015 \& beyond. “Disability inclusive development agenda towards 2015 \& beyond." Available online: http:/ /www.un.org/ en/development/desa/news/social/disability-inclusive-development.html (accessed on 25 August 2016).

116. Groce, Nora Ellen. Disability and the Millennium Development Goals: A Review of the MDG Process and Strategies for Inclusion of Disability Issues in Millennium Development Goal Efforts. New York: United Nations, 2011.

117. Scotch, Richard K. "Disability as the basis for a social movement: Advocacy and the politics of definition." Journal of Social Issues 44 (1988): 159-72. [CrossRef]

118. Kitchin, Rob. "'Out of place', 'knowing one's place': Space, power and the exclusion of disabled people." Disability \& Society 13 (1998): 343-56. [CrossRef]

119. Barnes, Marian, Janet Newman, Andrew Knops, and Helen Sullivan. “Constituting 'the public' in public participation." Public Administration 81 (2003): 379-99. [CrossRef]

120. Gilmartin, Ann, and Eamonn Slevin. “Original article: Being a member of a self-advocacy group: Experiences of intellectually disabled people." British Journal of Learning Disabilities 38 (2010): 152-59. [CrossRef]

121. United Nations. "Convention on the rights of persons with disabilities." Available online: http://www.un. org/disabilities/convention/conventionfull.shtml (accessed on 25 August 2016).

122. United Nations. "Why a convention?" Available online: http://www.un.org/disabilities/convention/ questions.shtml\#one (accessed on 25 August 2016). 
123. Petersen, Carole J. "Reproductive justice, public policy, and abortion on the basis of fetal impairment: Lessons from international human rights law and the potential impact of the convention on the rights of persons with disabilities." Journal of Law and Health 28 (2015): 121-63.

124. Government of Canada. "Bill C-6: An act respecting assisted human reproduction and related research." Available online: http:/ / www.parl.gc.ca/HousePublications /Publication.aspx?DocId=2331611\&File=25\& Language $=\mathrm{e} \&$ Mode $=1$ (accessed on 25 August 2016).

125. Mykitiuk, Roxanne, and Steven Penney. "Screening for deficits: The legal and ethical implications of genetic screening and testing to reduce health care budgets." Health Law Journal 3 (1995): 235-68. [PubMed]

126. Mykitiuk, Roxanne, Stephanie Turnham, and Mireille Lacroix. "Prenatal diagnosis and pre-implantation genetic diagnosis: Legal and ethical issues." In Genetic Testing: Care, Consent and Liability. Hoboken: John Wiley and Sons Inc., 2006.

127. Silvers, Anita, and Michael Ashley Stein. "Human rights and genetic discrimination: Protecting genomics' promise for public health." The Journal of Law, Medicine E Ethics 31 (2003): 377-89. [CrossRef]

128. Wolbring, Gregor. "Disability rights approach to genetic discrimination." In Society and Genetic Information: Codes and Laws in the Genetic Era. Edited by Judit Sandor. Budapest: CPS books Central European University Press, 2004, pp. 161-87.

129. Lotito, Michael, Brendan J. Fitzgerald, and Dominic LoVerde. "Recent developments in employment law and litigation." Tort Trial \& Insurance Practice Law Journal 51 (2016): 375-407.

130. Rothstein, Mark A., Jessica Roberts, and Tee L. Guidotti. "Limiting occupational medical evaluations under the Americans with disabilities act and the genetic information nondiscrimination act." American Journal of Law \& Medicine 41 (2015): 523-67. [CrossRef]

131. Stein, Michael Ashley, Anita Silvers, Bradley A. Areheart, and Leslie Pickering Francis. "Accommodating every body." The University of Chicago Law Review 81 (2014): 689-756.

132. Plümecke, Tino. "Genes, symptoms, and the 'asymptomatic ill': Towards a broader understanding of genetic discrimination." New Genetics and Society 35 (2016): 124-48. [CrossRef]

133. Adjin-Tettey, Elizabeth. "Potential for genetic discrimination in access to insurance: Is there a dark side to increased availability of genetic information." Alberta Law Review 50 (2012): 577-614.

134. De Paor, Aisling, and Delia Ferri. "Regulating genetic discrimination in the European Union." European Journal of Law Reform 17 (2015): 14. [CrossRef]

135. WHO. "Draft World Health Organization (WHO) guidelines on bioethics." Available online: http:/ /www. nature.com/wcs/b23a.html (accessed on 25 August 2016).

136. Weich, Ronald. "On behalf of the American Civil Liberties Union for inclusion in the record of the hearing of the senate committee on health, education, labor, and pensions on genetic privacy and non-discrimination." Available online: https://www.aclu.org/statement-legislative-consultant-ron-weich-genetic-privacy-andnon-discrimination-senate-health (accessed on 25 August 2016).

137. National Council on Disability (USA). "Position paper on genetic discrimination legislation." Available online: https://www.ncd.gov/publications/2002/March42002 (accessed on 25 August 2016).

138. Roberts, Jessica L. "Preempting discrimination: Lessons from the genetic information nondiscrimination act." Vanderbilt Law Review 63 (2010): 439-90.

139. Roberts, Jessica L. "The genetic information nondiscrimination act as an antidiscrimination law." Notre Dame Law Review 86 (2010): 597-648.

140. Green, Robert C., Denise Lautenbach, and Amy L. McGuire. "Gina, genetic discrimination, and genomic medicine." New England Journal of Medicine 372 (2015): 397-99. [CrossRef] [PubMed]

141. Parliament of Canada. "Bill S-201 genetic non-discrimination act: An act to prohibit and prevent genetic discrimination." Available online: http://www.parl.gc.ca/HousePublications/Publication.aspx?Language= E\&Mode $=1 \&$ DocId=8185825 (accessed on 25 August 2016).

142. Canadian Coalition for Genetic Fairness. "About genetic discrimination." Available online: http://ccgf-cceg. ca/en/about-genetic-discrimination/ (accessed on 25 August 2016).

143. Government of Norway. "UN convention on the rights of persons with disabilities-Norway's initial report." Available online: https:/ /www.regjeringen.no/contentassets/26633b70910a44049dc065af217cb201/crpdinitial-report-norway-english-01072015.pdf (accessed on 25 August 2016).

144. Malhotra, Ravi. "Has the charter made a difference for people with disabilities? Reflections and strategies for the 21st century." Supreme Court Law Review 58 (2012): 273-97. 
145. Court of Justice of the European Union. "Oined cases of Ring and Skouboe Werge." Available online: http:/ / curia.europa.eu/juris/document/document.jsf?text=\&docid=136161\&pageIndex=0\&doclang= $\mathrm{EN} \&$ mode $=$ req\&dir $=\& o c c=$ first\&part $=1 \&$ cid $=304756$ (accessed on 25 August 2016).

146. Flynn, Eilionoir. "New decision on disability discrimination from the CJEU." Available online: http:// europeanlawblog.eu/?tag=cases-c\%E2\%80\%9133511-and-c\%E2\%80\%9133711-ring-and-skouboe-werge (accessed on 25 August 2016).

147. Wolbring, Gregor, and Sophya Yumakulov. "Education through an ability studies lens." Zeitschrift für Inklusion, 2015. Available online: http://www.inklusion-online.net/index.php/inklusion-online/article/ view/278/261 (accessed on 25 August 2016).

148. Ball, Natalie, and Gregor Wolbring. "Cognitive enhancement: Perceptions among parents of children with disabilities." Neuroethics 7 (2014): 345-64. [CrossRef] [PubMed]

149. Wolbring, Gregor. "'Therapeutic', enhancement enabling, assistive devices and the un convention on the rights of persons with disabilities: A missing lens in the enhancement regulation discourse." Journal of International Biotechnology Law 6 (2009): 193-206. [CrossRef]

150. UNESCO. “Universal declaration on bioethics and human rights." Available online: http://www.unesco. org/new/en/social-and-human-sciences/themes/bioethics/bioethics-and-human-rights/ (accessed on 25 August 2016).

151. UNESCO. "International declaration on human genetic data." Available online: http://www. unesco.org/new/en/social-and-human-sciences/themes/bioethics/human-genetic-data/ (accessed on 25 August 2016).

152. Wolbring, Gregor. "Human enhancement: The need for ability expectation governance." Available online: http:/ / prism.Ucalgary.Ca/bitstream/1880/50371/1/echss_1_2015_wolbringenglishversion.Pdf (accessed on 25 August 2016).

(C) 2016 by the authors; licensee MDPI, Basel, Switzerland. This article is an open access article distributed under the terms and conditions of the Creative Commons Attribution (CC-BY) license (http://creativecommons.org/licenses/by/4.0/). 